\title{
Perbedaan Kadar Alpha 1 Antitrypsin Feses Berdasarkan Tingkat Keparahan Diare Akut pada Anak
}

Fitriyana, Yusri Dianne Jurnalis, Eti Yerizel*

Departemen Ilmu Kesehatan Anak, *Pasca sarjana Ilmu Biomedik Fakultas Kedokteran Universitas Andalas/ RSUP dr M Djamil, Padang

Latar belakang. Diare dapat menyebabkan kekurangan gizi, gangguan pertumbuhan dan gangguan kognitif. Gangguan gizi dapat terjadi karena asupan makanan yang kurang, atau kehilangan langsung karena kerusakan mukosa usus. Kehilangan protein melalui saluran cerna dapat dinilai dengan pemeriksaan kadar alpha 1 antitrypsin feses.

Tujuan. Menilai perbedaan kadar alpha 1 antitrypsin feses berdasarkan tingkat keparahan diare akut pada anak.

Metode. Penelitian cross sectional dari Januari-Juli 2017. Penelitian dilakukan di RSUP Dr M Djamil dan RS Yos Sudarso Padang. Tingkat keparahan diare dinilai menggunakan Vesikari clinical severity scoring system. Kadar alpha 1 antitrypsin feses diperiksa dengan cara ELISA. Analisis statistik menggunakan uji Kruskal-Wallis.

Hasil. Dari 60 subjek penelitian, rerata kadar alpha 1 antitrypsin adalah 202,32 $\pm 131,96 \mathrm{mg} / \mathrm{dL}$. Kadar alpha 1 antirypsin feses pada kelompok tingkat keparahan diare ringan didapatkan 123,6 (87-295,1) mg/dL. Pada kelompok tingkat keparahan diare sedang 166,4 $(23,8-332,9) \mathrm{mg} / \mathrm{dL}$ dan kelompok tingkat keparahan diare berat 268,6 (25,5-511,9) $\mathrm{mg} / \mathrm{dL}$. Uji analisis statistik menunjukkan terdapat perbedaan kadar alpha 1 antitrypsin feses yang signifikan pada setiap tingkat keparahan diare dengan nilai $\mathrm{p}=0,003$.

Kesimpulan. Terdapat peningkatan kadar alpha 1 anitripsin feses yang bermakna sesuai dengan tingkat keparahan diare. Sari Pediatri 2018;19(5):267-72

Kata kunci: tingkat keparahan diare akut, kadar alpha 1 anttitrypsin feses, anak

\section{The Differences in Alpha Level 1 Antitrypsin Feses Based on Acute Severity Diarrhea in Children}

Fitriyana, Yusri Dianne Jurnalis, Eti Yerizel*

Background. Diarrhea may lead to malnourished, growth disorder, and cognitive impairment. Nutritional disorders in diarrhea sufferers may occur of poor food intake, malabsorption due to intestinal mucosal damage, catabolism caused by the infection process and direct loss due to intestinal mucosal damage. Loss of protein through the gastrointestinal tract can be assessed by examination of alpha 1 antitrypsin of stool.

Objective. To determine the association of alpha 1 antitrypsin of stool with the severity level of diarrhea in children.

Methods. This study was cross sectional study from January-July 2017 conducted in RSUP DR M Djamil hospital and Yos Sudarso Hospital in Padang. The severity level of diarrhea was obtained by Vesikari clinical severity scoring system. Fecal alpha 1 antitrrypsin value conducted by ELISA. Statistical analysis was conducted by Kruskal Wallis test.

Result. From 60 subjects the mean age of alpha 1 antitrypsin was $202.32 \mathrm{mg} / \mathrm{dL} \pm 131.96$. Fecal alpha 1 antitrypsin value according to severity of the diarrhea was 123.6 (87-295.1) $\mathrm{mg} / \mathrm{dL}, 166.4$ (23.8-332.9) $\mathrm{mg} / \mathrm{dL}$, and 268.6 (25.5-511.9) $\mathrm{mg} / \mathrm{dL}$ respectively for mild, moderate and severe diarrhea. Based on statistical analysis there are significant differences between fecal alpha 1 antitrypsin value in every severity of diarrhea $(\mathrm{p}=0.003)$.

Conclusions: There is association in between alpha 1 antitrypsin level of stool with severity level of diarrhea. Sari Pediatri 2018;19(5):267-72

Keyword: severity level of diarrhea, alpha 1 antitrypsin of stool, children

Alamat korespondensi: dr. Fitriyana. Departemen Ilmu Kesehatan Anak FK-UNAND/RSUP dr.M.Djamil Jl.Perintis Kemerdekaan. Padang, Sumatera Barat. Email: fitriyanawinarno@yahoo.com 
$\mathrm{D}$ iare masih menjadi masalah kesehatan masyarakat di negara berkembang. Diare masih merupakan penyebab kematian kedua terbanyak pada anak dan diperkirakan terdapat 1,5 juta kematian akibat diare di dunia setiap tahunnya. Angka kematian akibat diare akut di negara maju masih mencapai 300 kematian pertahun. ${ }^{1}$ Penyakit ini juga merupakan salah satu penyebab kematian dan kesakitan tertinggi pada anak di Indonesia, terutama usia di bawah 5 tahun. Berdasarkan survei Riset Kesehatan Dasar (Riskesdas) tahun 2010 kejadian diare di Indonesia berkisar antara 4-19\% pada umumnya disebabkan oleh infeksi dan terjadi pada usia 6-24 bulan. ${ }^{2}$

Rotavirus merupakan penyebab utama diare dehidrasi berat di dunia. Rotavirus juga sering dihubungkan dengan diare infeksi akut dengan keparahan tinggi dan menyebabkan kematian. ${ }^{3,4}$ Setiap tahun, rotavirus menyebabkan hampir 114 juta kejadian diare dimana 25 juta kasus membutuhkan rawat jalan, 2,4 juta kasus membutuhkan perawatan di rumah sakit dan 610.000 kematian anak di bawah 5 tahun. ${ }^{5}$

Diare dapat menyebabkan kekurangan gizi, gangguan pertumbuhan dan gangguan kognitif terutama pada anak di negara berkembang. ${ }^{6}$ Gangguan gizi pada penderita diare dapat terjadi karena asupan makanan yang kurang, malabsorpsi karena kerusakan mukosa usus, katabolisme yang disebabkan oleh adanya proses infeksi dan kehilangan langsung karena kerusakan mukosa usus. ${ }^{7}$

Infeksi pada saluran cerna juga akan menyebabkan peningkatan kehilangan protein (enteric protein losses). Penyerapan nitrogen menurun $0,86 \%$ dan penyerapan lemak $0,4 \%$ untuk setiap gram peningkatan berat feses yang keluar. Reaksi inflamasi yang menyertai infeksi saluran cerna juga akan berkontribusi terhadap efek diare dalam memengaruhi status gizi. Pelepasan sitokin akan menyebabkan terjadinya peningkatan kebutuhan energi, penurunan nafsu makan, katabolisme serta hilangnya nutrisi dengan cepat. ${ }^{8-10}$

Pemeriksaan alpha-1 antitrypsin (AAT) feses merupakan pemeriksaan yang sangat berguna, tidak invasif dan praktis dalam memdeteksi hilangnya protein dari melalui usus. ${ }^{11,12}$ Pemeriksaan ini sebanding dengan pemeriksaan radioisotopik yang merupakan standar penilaian kehilangan protein pada saluran cerna. ${ }^{13}$ Konsentrasi AAT meningkat pada anak dengan gangguan intestinal dibanding anak normal. ${ }^{14,15}$ Konsentrasi AAT feses akan meningkat pada diare yang disebabkan oleh rotavirus, adenovirus, shigella, enterotoxigenic E coli (ETEC) dan salmonella. ${ }^{16}$ Penelitian ini bertujuan untuk melihat apakah terdapat perbedaan kadar alpha-1 antitrypsin feses pada tingkat keparahan diare akut pada anak.

\section{Metode}

Penelitian ini adalah penelitian cross sectional study. Penelitian ini dilakukan RSUP Dr M Djamil dan RS Yos Sudarso di kota Padang, dan pemeriksaan kadar alpha 1-antitrypsin feses dilakukan di laboratorium Biomedik Fakultas Kedokteran Universitas Andalas.

Populasi penelitian adalah semua penderita diare akut anak yang memenuhi kriteria inklusi dan ekslusi. Dengan tingkat kemaknaan $\alpha=0,05(Z \alpha=1,64)$, didapatkan jumlah sampel 60 orang. Sampel diambil dengan metode consecutive sampling. Kriteria inklusi adalah penderita diare akut berusia 6 bulan -60 bulan dan bersedia mengikuti penelitian. Kriteria ekslusi adalah anak dengan penyakit saluran cerna seperti chorn disease atau inflammatory bowel disease, anak yang menderita kelainan ginjal, hati, atau penyakit infeksi berat lainnya atau dengan gizi buruk.

Tingkat keparahan diare diukur dengan cara melakukan skoring. Sistem skoring yang dipergunakan merupakan turunan/modifikasi dari sistem skor yang didesain oleh Ruuska dan Vesikari pada tahun 1990, dan sudah teruji realiabilitas dan validitas internal oleh Freedman dengan Cronbach's $\alpha$ 0,59. Tingkat keparahan diare adalah ringan jika skor $<7$, sedang jika skor 7-10 dan berat jika skor $\geq 11$ (Tabel 1). ${ }^{17,18}$

Kadar $\alpha-1$ antytripsin feses diperiksa dengan metode enzyme linked immunosorbent assay (ELISA) secara in vitro, menggunakan Human a1-antitrypsin ELISA kit (bioassay technology laboratory). ${ }^{19}$

\section{Hasil}

Telah dilakukan penelitian terhadap penderita diare akut anak yang berobat dan dirawat di RSUP Dr. M. Djamil Padang dan RS Yos Sudarso Padang, mulai bulan Januari 2017 sampai Juni 2017. Selama periode penelitian, didapatkan 45 pasien di RSUP Dr. M. Djamil dan 15 pasien di RS. Yos Sudarso, Padang, yang memenuhi kriteria penelitian. Karakteristik subjek penelitian tertera pada Tabel 2.

Berdasarkan karakteristik didapatkan subjek 
Fitriyana dkk: Perbedaan kadar alpha 1 antitrypsin feses berdasarkan tingkat keparahan diare akut

Tabel 1. Vesikari clinical severity scoring system

\begin{tabular}{lccc}
\hline Parameter & \multicolumn{3}{c}{ Skor } \\
\cline { 2 - 4 } & 1 & 2 & 3 \\
\hline Lama diare (hari) & $1-4$ & 5 & $\geq 6$ \\
Frekuensi diare/hari & $1-3$ & $4-5$ & $\geq 6$ \\
Lama muntah (hari) & 1 & 2 & $\geq 3$ \\
Frekuensi muntah/hari & 1 & $2-4$ & $\geq 5$ \\
Suhu & $37,1-38,4$ & $38,5-38,9$ & $\geq 39$ \\
Dehidrasi & Tanpa dehidrasi & $1-5 \%$ & $\geq 6 \%$ \\
Terapi & Tanpa terapi & Cairan rehidrasi di & Cairan rehidrasi \\
& & minum & intravena \\
\hline
\end{tabular}

Tabel 2. Karakteristik subjek penelitian

\begin{tabular}{lcc}
\hline Karakteristik & $\mathrm{f}(\mathrm{n})$ & $(\%)$ \\
\hline Usia (bulan) & & \\
6-24 & 31 & 51,7 \\
24-60 & 29 & 48,3 \\
Jenis kelamin & & \\
$\quad$ Laki-laki & 38 & 63,3 \\
$\quad$ Perempuan & 22 & 36.7 \\
Status gizi & & \\
$\quad$ Kurang & 31 & 51,7 \\
$\quad$ Baik & 29 & 48,3 \\
Tingkat keparahan diare & & \\
$\quad$ Ringan & 13 & 21,7 \\
$\quad$ Sedang & 21 & 35 \\
$\quad$ Berat & 26 & 43,3 \\
Kadar albumin & $4,14 \mathrm{gr} / \mathrm{dL}$ & \\
\hline
\end{tabular}

penelitian usia 6 bulan sampai 24 bulan $31(51,7 \%)$, dan usia 24 sampai 60 bulan (48,3\%). Rerata usia subjek adalah 25 bulan (SD 16,66). Subjek penelitian lebih banyak laki-laki di bandingkan perempuan, masingmasing 38 (63,3\%) dan 22 (36,7\%). Berdasarkan status gizi didapatkan subjek dengan status gizi kurang 31 $(51,7 \%)$, lebih banyak dibanding status gizi baik yang berjumlah 29 (48,3\%).

Tingkat keparahan diare dinilai berdasarkan Vesikari clinical severity scoring system yang menilai secara klinis derajat dehidrasi serta terapi yang diberikan. Sebagian subjek penelitian mengalami diare berat 26 (43,3\%), diare sedang 21 (35\%), sedangkan derajat diare ringan $13(21,7 \%)$. Rerata kadar albumin didapatkan dari 30 subjek penelitian adalah $4,14 \mathrm{gr} /$ $\mathrm{dL}$ (SD 0,438), dengan nilai terendah $3,5 \mathrm{gr} / \mathrm{dL}$ dan tertinggi $5,1 \mathrm{gr} / \mathrm{dL}$. Pada penelitian ini tidak semua subjek penelitian di lakukan pemeriksaan kadar albumin.

Untuk menilai pengaruh status gizi terhadap tingkat keparahan diare dilakukan uji statistik chi square (Tabel 3). Dari 31 subjek dengan status gizi kurang, 45,2\% mengalami diare dengan tingkat keparahan berat. Dari 29 subjek dengan status gizi baik, 41,4\% mengalami diare dengan tingkat keparahan berat. Dari hasil uji statistik chi square didapatkan nilai $\mathrm{p}=0,201$, maka disimpulkan tidak terdapat perbedaan proporsi tingkat keparahan diare terhadap status gizi.

Hasil penelitian menunjukkan median kadar alpha 1 antitrypsin feses adalah 206,15 mg/dL (8,7-511,9 $\mathrm{mg} / \mathrm{dL}$ ). Berdasarkan uji Kolmogorov-Smirnov sebaran data kadar alpha 1 antitrypsin pada ketiga kelompok diare tidak terdistribusi normal (nilai $\mathrm{p}<0,05$ ). Untuk menilai perbedaan antara kadar alpha 1 antitrypsin feses dengan tingkat keparahan diare dilakukan uji statistik non parametrik Kruskal-Wallis.

Tabel 4 memperlihatkan rerata median kadar alpha 1 antitrypsin meningkat pada tingkat keparahan diare berat $(293,4 \mathrm{mg} / \mathrm{dL})$ dibandingkan dengan tingkat keparahan diare sedang $(191,3 \mathrm{mg} / \mathrm{dL})$ dan tingkat keparahan diare ringan $(90,5 \mathrm{mg} / \mathrm{dL})$. Uji analisis statistik Kruskal-Wallis menunjukkan terdapat perbedaan kadar alpha 1 antitrypsin feses yang signifikan pada setiap tingkat keparahan diare dengan nilai $\mathrm{p}=0,003$.

Untuk menentukan kelompok yang mempunyai perbedaan diantara ketiga tingkat keparahan diare, dilakukan analisis post hoc Mann-Whitney. Perbedaan kadar alpha 1 antitrypsin bermakna secara statistik, terdapat antara 2 kelompok, yaitu antara tingkat keparahan diare sedang dengan berat $(\mathrm{p}=0,007)$ dan antara tingkat keparahan diare ringan dengan berat $(\mathrm{p}=0,003)$. Tingkat keparahan diare ringan dengan sedang terdapat perbedaan kadar alpha 1 antitrypsin 
Fitriyana dkk: Perbedaan kadar alpha 1 antitrypsin feses berdasarkan tingkat keparahan diare akut

Tabel 3. Pengaruh status gizi terhadap tingkat keparahan diare

\begin{tabular}{llccccc}
\hline Status gizi & \multicolumn{4}{c}{ Tingkat keparahan diare (\%) } & \multirow{2}{*}{ Total } & \multirow{2}{*}{ p } \\
\cline { 2 - 5 } & & Ringan & Sedang & Berat & & 0,201 \\
\hline Gizi & Kurang & $4(12,9)$ & $13(41,9)$ & $14(45,2)$ & $31(51,7)$ & 0,201 \\
& Baik & $9(31)$ & $8(27,6)$ & $12(41,4)$ & $29(48,3)$ & \\
\hline Total & $13(21,7)$ & $21(35)$ & $26(43,3)$ & $60(100)$ & \\
\hline
\end{tabular}

Tabel 4. Perbedaan kadar alpha 1 antitrypsin berdasarkan tingkat keparahan diare

\begin{tabular}{lccc}
\hline Tingkat keparahan diare & $\mathrm{n}$ & $\begin{array}{c}\text { Kadar alpha } 1 \text { antitripsin feses }(\mathrm{mg} / \mathrm{dL}) \\
\text { Median }(\min -\max )\end{array}$ & $\mathrm{p}$ \\
\hline Ringan & 13 & $90,5(8,7-295,1)$ & \\
Sedang & 21 & $191,3(23,8-332,9)$ & 0,003 \\
Berat & 26 & $293,4(25,5-551,9)$ & \\
\hline
\end{tabular}

feses, tetapi secara statistik tidak bermakna $(\mathrm{p}>0,05)$.

\section{Pembahasan}

Jumlah akhir subjek penelitian yang dianalisis adalah 60 subjek. Pada penelitian ini, proporsi diare anak usia 6-24 bulan adalah $51,7 \%$ dan usia 24 bulan sampai 60 bulan adalah $48,3 \%$. Usia merupakan faktor yang berpengaruh terhadap kejadian diare. Balita usia kurang dari 2 tahun mempunyai risiko 3,18 kali lebih tinggi terkena diare akut dibandingkan balita berumur lebih dari dua tahun. ${ }^{20}$

Menurut jenis kelamin, populasi laki-laki pada penelitian ini lebih banyak dibanding perempuan. Penelitian lain berbasis rumah sakit yang dilakukan oleh Banerjee $\mathrm{dkk}^{21}$ di India juga mendapatkan lebih banyak populasi pasien laki-laki dibanding perempuan yang menderita diare akut. Penelitian ini tidak menganalisis penyebab terjadinya diare pada anak, tetapi berdasarkan literatur infeksi rotavirus merupakan penyebab diare tersering pada anak. ${ }^{22}$

Status gizi dinilai berdasarkan grafik z-score. Dari 60 subjek penelitian didapatkan 51,7\% dengan status gizi kurang dan 48,3\% dengan status gizi baik. Adisasmito ${ }^{23}$ yang meneliti tentang faktor risiko diare pada bayi dan balita di Indonesia melaporkan bahwa status gizi memiliki faktor risiko yang bermakna menyebabkan penyakit diare pada bayi dan balita. Hasil penelitian Brown ${ }^{24}$ juga melaporkan bahwa beberapa faktor risiko penyebab diare adalah faktor antropometrik, pola pemberian makanan, dan status nutrisi mikro. Status gizi tidak berpengaruh terhadap tingkat keparahan diare. Hasil tersebut tidak berbeda dengan penelitian Weizman $\mathrm{dkk}^{10}$ yang melaporkan bahwa korelasi antara lama diare dengan status gizi tidak ditemukan.

Tingkat keparahan diare dinilai berdasarkan Vesikari clinical severity scoring system. Ditemukan 43,3\% diare dengan derajat berat . Rotavirus merupakan penyebab utama diare. Berdasarkan literatur, rotavirus juga sering dihubungkan dengan diare infeksi akut dengan keparahan tinggi dan menyebabkan kematian. ${ }^{3}$ Gejala klinis yang sering muncul adalah demam, diare, dan muntah. Hampir semua subjek penelitian mengalami ketiga gejala tersebut dengan derajat yang berbeda. Sebagian besar pasien mengalami dehidrasi sedang dan mendapat cairan rehidrasi intravena sehingga banyak subjek mendapatkan total skor keparahan diare lebih dari 11 (tingkat keparahan diare berat). Penelitian ini juga dilakukan di rumah sakit swasta yang sebagian besar pasien mendapat cairan intravena. Hal tersebut menyebabkan kerancuan dalam penilaian skoring tingkat keparahan diare.

Infeksi usus sering menyebabkan protein endogen hilang, terutama setelah infeksi bakteri invasif. Pemeriksaan kadar alpha 1 antitrypsin feses merupakan salah satu cara untuk menilai kehilangan protein melalui saluran cerna. Dibanding pemeriksaan ${ }^{51} \mathrm{Cr}-$ albumin secara radioaktif, pemeriksaan kadar alpha 1 antitrypsin feses lebih aman, mudah dilakukan, dan lebih dapat diandalkan. ${ }^{8,25}$ Berdasarkan penelitian yang dilakukan Megazzu dkk ${ }^{13}$ terdapat peningkatan rerata kadar alpha 1 antitrypsin feses pasien dengan gangguan saluran cerna dibanding kelompok kontrol. Begitu 
juga dengan penelitian yang dilakukan Tangsilsat $\mathrm{dkk}^{14}$ didapatkan median kadar alpha 1 antitrypsin feses pada anak dengan gangguan saluran cerna lebih tinggi dibanding anak sehat usia 1 bulan-15 tahun.

Kadar alpha 1 antitrypsin feses dianggap normal jika kurang dari $54 \mathrm{mg} / \mathrm{dL}$ pada sebagian besar laboratorium. ${ }^{26}$ Pada penelitian ini didapatkan rerata kadar alpha 1 antitrypsin 202,32 mg/dL $\pm 131,96$, $85 \%$ subjek penelitian memiliki kadar alpha 1 antitrypsin lebih dari $54 \mathrm{mg} / \mathrm{dL}$. Penelitian ini sesuai dengan yang dilakukan Darani $\mathrm{dkk}^{27}$ bahwa terdapat peningkatan kadar alpha 1 antitrypsin feses yang bermakna pada kelompok diare dibanding kelompok kontrol yang tidak diare. Strygler $\mathrm{dkk}^{15}$ juga menguji perbedaan kadar alpha 1 antitrypsin feses pada pasien dengan gangguan saluran cerna, termasuk diare, dan didapatkan peningkatan jika dibandingkan dengan kelompok yang normal.

Rata-rata kadar alpha 1 antirypsin feses pada subjek kelompok tingkat keparahan diare ringan adalah 123,6 (87-295,1) mg/dL. Pada kelompok tingkat keparahan diare sedang $166,4(23,8-332,9)$ $\mathrm{mg} / \mathrm{dL}$. Pada kelompok tingkat keparahan diare berat 268,6 (25,5-511,9) mg/dL. Berdasarkan uji statistik yang dilakukan terdapat perbedaan bermakna rerata kadar alpha 1 antitrypsin feses berdasarkan tingkat keparahan diare. Perbedaan kadar alpha 1 antitrypsin feses ditemukan pada dua kelompok, yaitu kelompok tingkat keparahan diare sedang dengan berat dan antara kelompok tingkat keparahan diare ringan dengan berat. Nilai standar deviasi rerata kadar alpha 1 antitrypsin berdasarkan tingkat keparahan diare dinilai cukup besar. Hal tersebut dapat terjadi karena tingkat keparahan diare tidak saja menilai frekuensi dan lama diare, tetapi juga frekuensi dan lama muntah, lama demam, derajat dehidrasi, dan terapi yang diberikan.

Peningkatan kadar alpha 1 antitrypsin terjadi sejalan dengan tingkat keparahan diare. Peningkatan volume tinja yang keluar (lebih dari $30 \mathrm{ml} / \mathrm{kg} /$ hari) berhubungan dengan balance negatif untuk penyerapan protein, lemak, dan karbohidrat. Infeksi usus sering menyebabkan peningkatan protein endogen hilang, terutama setelah infeksi bakteri invasif. ${ }^{8}$ Berdasarkan literatur disebutkan bahwa diare yang disebabkan rotavirus cenderung lebih berat dibanding dengan diare yang disebabkan patogen lain. ${ }^{28}$ Sejalan dengan penelitian yang dilakukan Aulia $\mathrm{dkk}^{16}$ terjadi peningkatan kadar alpha 1 antitrypsin feses pada diare akut akibat rotavirus dibanding kelompok non-rotavirus.
Peningkatan kehilangan protein melalui saluran cerna akan menyebabkan terjadinya protein losing enteropathy. Kondisi ini ditandai dengan peningkatan kadar alpha 1 antitrypsin, biasanya lebih dari $54 \mathrm{mg} /$ dL dan penurunan kadar albumin serum di bawah 3 gr/dL. ${ }^{29}$ Pada penelitian ini belum terjadi protein losing enteropathy, sebagian besar kadar alpha 1 antitrypsin di atas $54 \mathrm{mg} / \mathrm{dL}$, tetapi tidak ditemukan penurunan kadar albumin serum. Rerata kadar albumin serum adalah 4,14 gr/dL. Hasil tersebut sejalan dengan penelitian Weizman $\mathrm{dkk}^{10}$ yang melaporkan bahwa meskipun terjadi peningkatan kadar alpha 1 antitrypsin pada anak yang mengalami diare akut dan persisten dibanding kontrol, tetapi kadar albumin serum masih dalam rentang batas normal.

\section{Kesimpulan}

Rerata kadar alpha 1 antitrypsin feses pada pasien diare akut meningkat berdasarkan tingkat keparahan diare. Terdapat perbedaan antara kadar alpha 1 antitrypsin berdasarkan tingkat keparahan diare berat dengan diare sedang, dan ringan. Pasien dengan gizi kurang cenderung mengalami diare dengan tingkat keparahan berat, tetapi tidak bermakna secara statistik.

Disarankan untuk melakukan penelitian lebih lanjut mengenai faktor yang memengaruhi tingkat keparahan diare, seperti penyebab diare pada anak. Diperlukan penelitian lebih lanjut untuk melihat hubungan kejadian protein losing enteropathy dengan tingkat keparahan diare.

\section{Daftar pustaka}

1. Guerrant RL, Gilder TV, Steiner TS, Thielman NM, Slutsker L, Tauxe RV, dkk. Practice guidelines for the management of infectious diarrhea. Clin Infect Dis 2001;32:331-50.

2. Badan Penelitian dan Pengembangan Kesehatan Departemen Kesehatan RI. Laporan nasional riset kesehatan dasar tahun 2010. Jakarta: Depkes RI; 2010.

3. Mota-Hernandez F, Calva JJ, Gutie'rrez-Camacho C, VillaContreras S, Arias CF, Padilla-Noriega L, dkk. Rotavirus diarrhea severity is related to the VP4 type in Mexican children. J Clin Microbiol 2003;41:3158-62.

4. Albano F, Bruzzese E, Bella A, Cascio A, Titone L, Arista S, dkk. Rotavirus and not age determines gastroenteritis severity in children: a hospital-based study. Eur J Pediatr 2007;166:241-7. 
Fitriyana dkk: Perbedaan kadar alpha 1 antitrypsin feses berdasarkan tingkat keparahan diare akut

5. Rossignol JF. Infectious diarrhea-etiology, diagnosis, and treatment. US Gastrol Rev 2007:78-80.

6. M Farthing, M Salam, G Lindberg, dkk. Acute diarrhea in adults and children: a global perspective. World Gastroenterology Organisation Global Guidelines, 2012. Diakses pada 4 Februari 2018. Didapat dari: http://www.worldgastroenterology.org/ guidelines/global-guidelines/acute-diarrhea.

7. Halaby H, Bakheet SM, Shabib S, Powe JE, Mehaidib AA, Nazer H. 99mTcHumafl Serum Albumin Scans in Children with Protein-Losing Enteropathy. J Nucl Med 2000;41:215-9.

8. Nel ED. Diarrhoea and malnutrition. S Afr J Clin Nutr 2010;23:Supplement:S15-8.

9. Pariawihardja IS. Tinjauan terapi nutrisi pada diare anak. Semarang: Universitas Diponegoro; 1994.

10. Weizman Z, Binsztok M, Fraser D, Deckelbaum RJ, Granot E. Intestinal Protein Loss in Acute and Persistent Diarrhea of Early Childhood. J Clin Gastroenterol 2002;34:427-9.

11. Maki M, Harmoinen A, Vesikari T, Visakorpi J. Fecal excretion of alpha-1 antitrypsin in acute diarrhea. Arch Dis Child 1982 57:154-6.

12. Dinari G, Rosenbach Y, Zahavi I, Sivan Y, Nitzan M. Random fecal alpha1-antitrypsin excretion in children with intestinal disorders. Am J Dis Child 1984;138:971-3.

13. Megazzu G, Jacono G, Pasquale GD, dkk. Reliability and usefulness of random fecal alpha-1 antitrypsin concentration: Further simplification of the method. J Pediatr Gastroenterol Nutrit 1985;4:402-7.

14. Tangsilsat D, Atamasirikul K, Treepongkaruna S, Nathsevee S, Sumritsopak R, Kunakorn M. Fecal alpha1 - antitrypsin in healthy and intestinal-disorder thai children. J Med Assoc Thai 2007;90:1317-22.

15. Strygler B, Nicar MJ, Santangelo WC, Porter JL, Fordtran JS. Alpha 1-antitrypsin excretion in stool in normal subjects and in patients with gastrointestinal disorders. Gastroenterol 1990;99:1380-7.

16. Aulia D, Timan IS, Firmansyah A. Fecal alpha-1 antitrypsin concentration in protein-losing enteropathies caused by Rotavirus and enteropathogenic bacteria infection. Paediatr Indones 2009;49:315-21.

17. Schnadower D, Tarr PI, Gorelick MH, O'Connell K,
Roskind CG, Powell EC, dkk. Validation of the modified Vesikari score in children with gastroenteritis in 5 U.S. Emergency Departments. J Pediatr Gastroenterol Nutr 2013 57:514-9.

18. Freedman SB, Eltorky M, Gorelick M. Evaluation of a gastroenteritis severity score for use in outpatient settings. Pediatrics 2010;125:e1278-e85.

19. Catalog. Human $\alpha 1$-antitrypsin ELISA kit In: Bioassay Technology Laboratory.

20. RI PddiK. Situasi diare di Indonesia. Buletin Jendela Data dan Informasi Kesehatan 2011;2:1-18.

21. Banerjee I, Ramani S, Primrose B, Moses P, Iturriza-Gomara M, Gray JJ, dkk. Comparative study of the epidemiology of rotavirus in children from a community-based birth cohort and a Hospital in South India. J Clin Microbiol 2006;44:2468-74.

22. Guandalini S, Kahn SA. Acute diarrhea. Dalam: Walker, Goutlet, Klienmann, penyunting. Walker Pediatrics Gastrointestinal Diseases. Edisi ke-5. Ontario: BC Decker; 2008,

23. Adisasmito W. Faktor risiko diare pada bayi dan balita di Indonesia: Systematic review penelitian akademik bidang kesehatan masyarakat. Makara Kesehatan 2007;11:1-10.

24. Brown KH. Diarrhea and malnutrition. J Nutr 2003:328S-32.

25. Quigley EMM, Ross IN, Haeney MR, Holbrook IB, Marsh MN. Reassessment of faecal alpha-1antitrypsin excretion for use as screening test for intestinal protein loss. J Clin Pathol 1987;40:61-6.

26. Silvester FA. Protein losing enteropathy. Dalam: Wyllie R, Hyams JS, penyunting. Pediatric Gastrointestinal and Liver Disease: Elsevier Health Sciences; 2010.

27. Darani HY, Rahimian G, Nafisi M, Amini SA, Najafi A, Sarafpoor M. Unsuitability of fecal alpha 1-antitrypsin as a marker for differentiation of microbial and non-microbial diarrhea. Kuwait Med J 2005;37:91-3.

28. Surendran S. Rotavirus infection : molecular changes and patophysiology. EXCLI Journal 2008;7:154-62.

29. John AS, Johnson JA, Khan M, Driscoll DJ, Warnes CA, Cetta F. Clinical outcomes and improved survival in patients with protein-losing enteropathy after the fontan operation. J Am College Cardiol 2014;64:54-62. 